\title{
Molecular Anatomy of the Hair Cell's Ribbon Synapse
}

\author{
Revathy C. Uthaiah and A. J. Hudspeth \\ Howard Hughes Medical Institute and Laboratory of Sensory Neuroscience, The Rockefeller University, New York, New York 10065
}

Hearing depends on reliable and temporally precise neurotransmission by cochlear hair cells. The wide dynamic range and high sensitivity with which these cells encode acoustic stimuli are associated with a presynaptic specialization termed the presynaptic dense body or synaptic ribbon. Apposed to the presynaptic density, this spherical or flattened structure tethers a layer of synaptic vesicles and is thought to facilitate their exocytotic fusion. Although defining the molecular constituents of the hair cell's synaptic ribbon should contribute to our understanding of neurotransmitter release at this synapse, accomplishing this task has been slowed by the difficulty of obtaining sufficient amounts of starting material for protein analysis from hair cells. We isolated synaptic material from chicken cochleas, purified synaptic ribbons with specific immunological reagents, and identified the associated proteins by tandem mass spectrometry. Purification of the ribbons revealed a predominant composition of C-terminal-binding proteins, especially ribeye, in association with the small GTPase Rab3, which is possibly involved in attaching vesicles to the ribbon. In comparison with the components of conventional synapses and of retinal ribbon synapses, we observed that certain regulatory proteins are excluded from the hair cell's synapse. Using antisera against several of the novel proteins and membrane-trafficking components that we had identified, we documented their localization in isolated hair cells. Our results indicate that the ribbon synapses of hair cells display modifications to the presynaptic machinery that are associated with the high-fidelity transmission of acoustic signals to the brain.

\section{Introduction}

Synaptic transmission by the sensory receptors of the visual, auditory, and vestibular systems is characterized by tonic and graded neurotransmitter release that requires sustained high rates of exocytosis (Roberts et al., 1991; Lenzi and von Gersdorff, 2001; Sterling and Matthews, 2005). The presynaptic active zones of these glutamatergic synapses are marked by synaptic ribbons, flattened or ovoid electron-dense structures $100-1000 \mathrm{~nm}$ in diameter. Numerous synaptic vesicles are tethered by fine filaments to each ribbon.

The speed with which acoustic stimuli are encoded at the hair cell's ribbon synapse plays a key role in determining auditory representations in the CNS. Neurotransmitter release in hair cells exhibits fast kinetics, allowing acoustic stimuli to be encoded with a temporal resolution of $<1$ ms (Nouvian et al., 2006). Measurements of hair-cell membrane capacitance and turnover rates (Parsons et al., 1994; Moser and Beutner, 2000; Khimich et al., 2005; Rutherford and Roberts, 2006) and recordings from afferent neurons (Glowatzki and Fuchs, 2002; Keen and Hudspeth, 2006; Rutherford and Roberts, 2006, 2009; Li et al., 2009) suggest

Received Feb. 25, 2010; revised July 10, 2010; accepted July 19, 2010.

This work was supported by Grant DC000241 from the National Institutes of Health. R.C.U. was a recipient of a Women and Science Postdoctoral Fellowship from The Rockefeller University. A.J.H. is an Investigator of Howard Hughes Medical Institute. We are grateful to Ms. Y. Castellanos for assistance with the dissections and biochemical procedures and to Dr. K. Uryu for conducting the electron-microscopic studies. Dr. M. Oeffinger and Dr. M. P. Rout offered helpful discussions on magnetic beads, and Dr. H. Yu provided assistance with mass spectrometry. We thank the members of our research group, especially Dr. J. A. N. Fisher, Dr. E. C. Keen, Mr. L. Kowalik, and Dr. S. Lagier, for comments on this manuscript.

Correspondence should be addressed to A. J. Hudspeth, Howard Hughes Medical Institute and Laboratory of Sensory Neuroscience, The Rockefeller University, 1230 York Avenue, New York, NY 10065-6399. E-mail: hudspaj@rockefeller.edu.

DOI:10.1523/JNEUROSCI.1014-10.2010

Copyright $\odot 2010$ the authors $\quad 0270-6474 / 10 / 3012387-13 \$ 15.00 / 0$ that the ribbon synapse is optimized to release large amounts of neurotransmitter continuously and indefinitely. This exceptional rate of exocytosis places high demands on the synapse to replenish the active site with vesicles, a role thought to be played by the synaptic ribbon.

Despite their functional differences, ribbon synapses and conventional synapses have molecular similarities. The expression of soluble $N$-ethylmaleimide-sensitive factor (NSF) attachment protein (SNAP) receptors (SNAREs) is highly conserved. Syntaxin 1, SNAP25, and vesicle-associated membrane protein (VAMP1, synaptobrevin 1) occur at hair-cell synapses (Safieddine and Wenthold, 1999), and syntaxin 3, SNAP25, and VAMP3 (cellubrevin, synaptobrevin-3) are found at retinal synapses (Von Kriegstein et al., 1999; Lenzi and von Gersdorff, 2001). However, all ribbon synapses appear to lack the vesicle-associated synapsins 1 and 2. The hair-cell synapse lacks complexins (Strenzke et al., 2009), synaptophysins 1 and 2, and synaptotagmins 1 and 2 (Safieddine and Wenthold, 1999), proteins that are abundantly expressed at both conventional synapses and retinal ribbon synapses.

The specialized components of ribbon synapses have been described in the retina (tom Dieck et al., 2005), in which ribbons contain three members of the C-terminal-binding protein (CtBP) family of transcriptional repressors: CtBP1, CtBP2, and its alternative splice form ribeye (Magupalli et al., 2008; Schmitz, 2009). Two proteins have been identified as binding partners of ribeye in photoreceptor ribbons: munc119, a prenyl-binding protein (Alpadi et al., 2008), and IQ-ArfGEF (BRAG1), a guanine-nucleotide exchange factor for ADP-ribosylation factors (Katsumata et al., 2009). Cytomatrix proteins such as piccolo, Rab3-interacting molecule 1 (RIM1), and KIF3A are also associated with the ribbon, and active-zone scaffolding molecules such 
as bassoon, RIM2, ERC2 (CAST1), and munc13-1 tether the ribbon to the presynaptic membrane (tom Dieck et al., 2005).

Understanding of the molecular composition of the hair cell's ribbon synapse has remained limited (Nouvian et al., 2006; LoGiudice and Matthews, 2009), mostly because of the effort required in harvesting sufficient cochlear material for protein analysis. We have used biochemical and proteomic approaches to isolate presynaptic components from chicken cochleas and identified the proteins by tandem mass spectrometry (MS-MS).

\section{Materials and Methods}

Animals and organs. White Leghorn chickens (Gallus gallus) two weeks of age were killed with $\mathrm{CO}_{2}$ and decapitated. We dissected their cochleas in chick saline solution consisting of the following (in $\mathrm{mm}$ ): $154 \mathrm{NaCl}, 6 \mathrm{KCl}, 5.6$ $\mathrm{CaCl}_{2}, 2.3 \mathrm{MgCl}_{2}, 8$ D-glucose, and 5 HEPES, $\mathrm{pH}$ 7.4. The specimens were immediately frozen in liquid nitrogen and preserved at $-80^{\circ} \mathrm{C}$ until use. Cochlear and utricular hair cells were isolated from mice (Mus musculus; strain C57B/6) 1 to 2 weeks of age (He and Dallos, 2000). Mouse and chicken brains were isolated from animals 2 weeks of age and stored at $-80^{\circ} \mathrm{C}$ after homogenization in radioimmunoprecipitation assay (RIPA) lysis solution containing $150 \mathrm{~mm} \mathrm{NaCl}, 1 \%$ Igepal-40, 1\% sodium deoxycholate, $0.1 \%$ SDS, and $25 \mathrm{~mm}$ tris(hydroxymethyl)aminomethane at $\mathrm{pH}$ 7.6. Mouse retinal lysate was purchased (Anaspec). To produce chicken retinal lysate, we dissected neural retinas from pigment epithelia and homogenized them in RIPA solution.

Antibodies. Antisera and antibodies against the following proteins were purchased from the indicated sources: calcium/calmodulindependent serine protein kinase (CASK), CtBP1, CtBP2, dynamin, munc13, munc18, $\mathrm{N}$-cadherin, neuroligin, Rab3, RIM1, synapsin 1, synaptotagmin 1 , syntaxin 4 , syntaxin 6 , tomosyn, VAP-33, valosin-containing protein (VCP), and $\beta$-catenin were from BD Transduction Laboratories; actin, KIF3A, nonmuscle myosin heavy chain (MYH9), NF68, NF160, NF200, NSF, SNAP23, syntaxin 1, syntaxin $7, \alpha$-tubulin, $\gamma$-tubulin, chicken spectrin, and PRPF39 were from Sigma Immunochemicals; ERC2, piccolo, RIM2, synaptojanin, and VAMP3 were from Synaptic Systems; bassoon, NIPSNAP1, SNAP25, and VAMP1 were from Abcam; CaBP4, synaptophysin $1, \alpha$-SNAP, and $\beta$-SNAP were from Santa Cruz Biotechnology; GFAP and Sec13 were from Novus Biologicals; $\mathrm{Ca}^{2+}$ / calmodulin-dependent kinase II (CaMKII) was from Cell Signaling Technology; clathrin heavy chain was from Affinity BioReagents; complexin 1 and complexin 2 were from Millipore Bioscience Research Reagents; SV2 was from the Developmental Hybridoma Bank; glyceraldehyde phosphate dehydrogenase (GAPDH) was from Millipore; cysteine string protein (CSP) and VAMP2 were from Stressgen; and
A

Cochleas homogenized in buffered sucrose $1,500 \mathrm{xg}$ spin for $15 \mathrm{~min}$

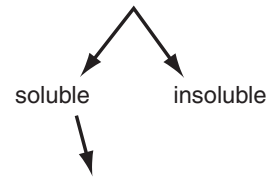

$20,000 \times$ g spin for $30 \mathrm{~min}$

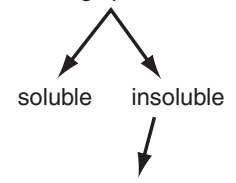

Cell lysis by hypoosmotic shock for $45 \mathrm{~min}$ $47,000 \times$ g spin for $15 \mathrm{~min}$

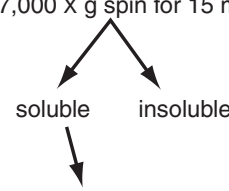

$200,000 \times$ g spin for $60 \mathrm{~min}$


Figure 1. Fractionation of presynaptic proteins $A$, A flow chart describes the purification of the presynaptic material from the retina and cochlea by differential and sucrose-gradient centrifugation. $B$, Immunoblotting delineates the fractionation of the ribbon proteins ribeye and CtBP2, the vesicle protein VAMP2, and the membrane SNARE syntaxin 1 in the retina and cochlea. 
A

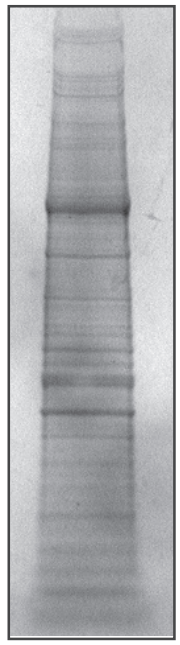

Synaptic fractionate from cochleas
B

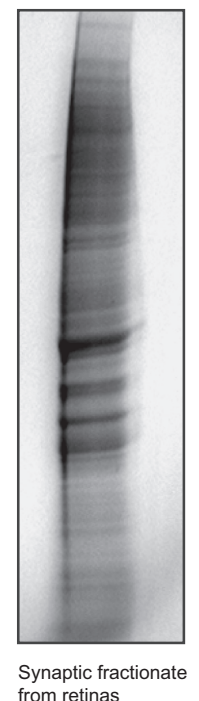

C

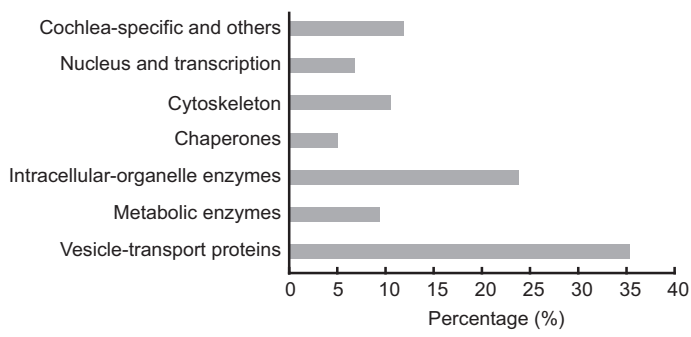

D

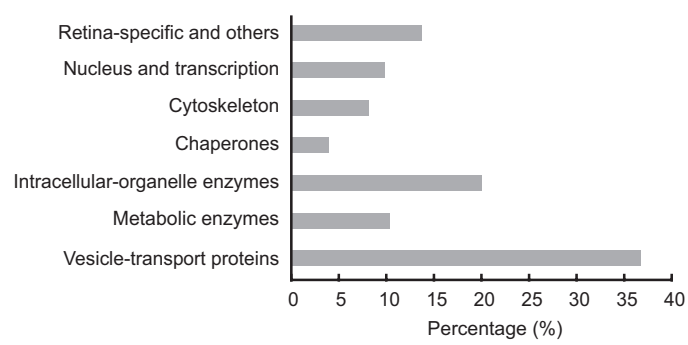

Figure 2. Purification and identification of presynaptic proteins from chicken cochleas and bovine retinas. $A$, Synaptic components purified from chicken cochleas were fractionated by density-gradient centrifugation and the ribbon-enriched fraction was separated by one-dimensional denaturing SDS-PAGE. $\boldsymbol{B}$, Similar procedures were applied to bovine retinas. $\boldsymbol{C}$, Bands were cut from the gel in $A$ and treated with trypsin; the digested peptides were subjected to LC-MS/MS. The histogram indicates the percentages of the identified proteins in various categories. $D$, A similar analysis was conducted for the retinal proteins. The specific proteins from the cochlea and retina are tabulated in, respectively, supplemental Tables 2 and 3 (available at www.jneurosci.org as supplemental material).

endophilin was from Zymed Laboratories. Additional details are provided in supplemental Table 1 (available at www.jneurosci.org as supplemental material).

Isolation of presynaptic proteins. The presynaptic components from chicken cochleas and bovine retinas were purified using a standard protocol (Huttner et al., 1983) with a few modifications. Approximately 2000 chicken cochleas were dissected and cryomilled with Mixer Mills MM301 (Retsch) and homogenized with a Kontes mortar and pestle (Daigger) in a solution containing $320 \mathrm{~mm}$ sucrose, $1 \mathrm{~mm}$ magnesium acetate, $0.5 \mathrm{~mm}$ calcium acetate, and $1 \mathrm{~mm}$ sodium bicarbonate at $\mathrm{pH}$ 7.2. The homogenate was centrifuged at $1500 \times g$ for 15 min to pellet large cell bodies, red blood cells, and myelin. The supernatant was removed, transferred to a fresh tube, and centrifuged again at $20,000 \times g$ for 30 min. The crude synaptosomal pellet was resuspended in a hypotonic solution containing $6 \mathrm{~mm}$ tris(hydroxymethyl)aminomethane maleate at pH 8.1, homogenized with 10 strokes of a Dounce homogenizer (Pyrex; Corning) in the presence of protease inhibitors, and incubated on ice for $45 \mathrm{~min}$ with intermittent vortexing to ensure cell lysis. The crude synaptosome fraction was centrifuged at $47,000 \times g$ for $15 \mathrm{~min}$ in a SW55 Ti Rotor (Beckman) to remove large membrane components. The supernatant was collected and small membrane components and synaptic vesicles were pelleted by centrifugation at $200,000 \times g$ in a SW2 8 rotor (Beckman) for $60 \mathrm{~min}$. A solution of $320 \mathrm{~mm}$ sucrose, Complete Protease Inhibitor Cocktail (Roche), and $10 \mathrm{~mm}$ HEPES at pH 7.4 was added to the pellets and the mixture was homogenized using a small glass Wheaton mortar with a Teflon pestle (Pyrex; Corning) to dissolve all the membrane pieces. The crude vesicle suspension was diluted into $200 \mathrm{~mm}$ sucrose, then layered on top of a step gradient containing 200, 400,600, and $800 \mathrm{~mm}$ sucrose and centrifuged at $100,000 \times g$ for $120 \mathrm{~min}$. The proteins fractionated between the sucrose layers were collected. All these samples and the $47,000 \times g$ pellet sample were separated by denaturing SDS-PAGE and stained with colloidal Coomassie Blue (Pierce). One millimeter bands were cut from the gel for mass-spectrometric analysis.

To purify presynaptic components from the bovine retina, we used eight retinas and followed the procedure described above.
All chemicals were obtained from SigmaAldrich unless otherwise specified.

SDS PAGE and immunoblotting. Samples were solubilized in NuPAGE LDS sample buffer and NuPAGE reducing agent, incubated at $100^{\circ} \mathrm{C}$, and loaded on linear-gradient $4-12 \%$ Bis-Tris gels (Invitrogen). Samples were subsequently electrotransferred to polyvinylidene fluoride membranes (Immobilon-P; Millipore) with the Trans-Blot SD semidry transfer apparatus (Bio-Rad). Immunocomplexes were visualized on film with horseradish peroxidase-conjugated secondary antibodies and enhanced chemiluminescence detection (ECL Plus; GE Healthcare). Chemiluminescence was detected with Classic Blue Autoradiography Films (MidSci) developed in a Konica SRX 101-A Processor.

Liquid chromatography-tandem mass spectrometry. Bands $1 \mathrm{~mm}$ in length were excised from SDS-PAGE gels and subjected to in-gel trypsin digestion and peptide extraction (Kumarathasan et al., 2005). In brief, the proteins were reduced with $10 \mathrm{~mm}$ dithiothreitol, alkylated with $55 \mathrm{~mm}$ iodoacetamide, and digested overnight at $37^{\circ} \mathrm{C}$ with sequencing-grade modified trypsin (Promega) in ammonium bicarbonate buffer. The digested products were extracted twice with $0.1 \%$ trifluoroacetic acid, $50 \%$ acetonitrile, and $1 \%$ trifluoroacetic acid. The extracted mixture was dried by Speed-Vac and redissolved in $10 \mathrm{ml}$ of $0.1 \%$ trifluoroacetic acid. The extracts were subjected to liquid chromatography-tandem mass spectrometry (LC-MS/MS) analysis. The pool of peptides was first separated in a reverse-phase liquid chromatography column with the Dionex U3000 Capillary/nano-HPLC system at a flow rate of $250 \mathrm{ml} / \mathrm{min}$, and then directly introduced by electrospray into a LTQ-Orbitrap mass spectrometer (Thermo Fisher Scientific) operated in data-dependent scan mode. A fused-silica capillary column $75 \mathrm{~mm}$ in internal diameter and $100 \mathrm{~mm}$ in length (Upchurch Scientific) was packed with C-18 resin (300 A; 5 $\mathrm{mm}$; Varian). Mobile phase solvent A contained 0.1\% formic acid and mobile phase solvent B contained $99.9 \%$ acetonitrile and $0.1 \%$ formic acid. Gradient runs for 60 min were performed in solvent B with a flow rate of $250 \mathrm{nl} / \mathrm{min}$. The mass-acquisition method involved one massspectrometric scan followed by six tandem scans in the ion trap. The initial scan was acquired for mass-to-charge $(\mathrm{m} / \mathrm{z})$ ratios of 400 to 1600. The six most intense peaks from each scan were selected in the ion trap for further fragmentation and tandem mass spectrometry.

The results were analyzed and the peptides as well as the parent proteins for chicken and bovine experiments were identified in the National Center for Biotechnology Information nonredundant database, NCBInr, choosing Chordata, with the MASCOT software search algorithm (MatrixScience) and the following parameters: missed cleavage, 1; fixed modification, carbamidomethylation; variable modification, oxidation of methionine. The maximum error tolerance was $20 \mathrm{ppm}$ for mass-spectrometric scans and 1.2 Da for tandem scans. We used stringent criteria for protein identification: a protein was designated as a "hit" only if it matched at least two distinct peptides with an ion score of at least 40. A single-peptide match was considered if the peptide yielded good tandem mass spectra and matched only one protein. The ion score, which is given by $-10 \cdot \log (P)$, in which $P$ is the probability that the observed match is a random event, indicates how well a spectrum matches a particular peptide. Individual ion scores exceeding 38 indicate identity or extensive homology at the level $p<0.05$. For proteins matching the same sets of peptides, only the protein with the greatest percentage of peptide representation was selected.

Isolation of hair cells and immunocytochemistry. The dissected chicken's cochlea was pinned at both ends, and the tegmentum vasculosum was 
removed with fine forceps. The basilar papilla and tectorial membrane were separated from the rest of the tissue and placed in fresh chick saline solution. The sample was triturated 10 times through a trimmed $200 \mu \mathrm{l}$ pipette tip to separate the tectorial membrane and free individual cells. Isolated cells were allowed to settle onto coverslips coated with 1 $\mathrm{mg} / \mathrm{ml}$ concanavalin A. The cells were fixed for 20 min with $4 \%$ formaldehyde in $10 \mathrm{~mm}$ PBS at pH 7.4, permeabilized for 15 min with $0.05 \%$ Triton X-100 in PBS, and blocked for $30 \mathrm{~min}$ with $0.05 \%$ Triton X-100 in PBS with $1 \%$ normal serum from the species (goat, mouse, or rabbit) in which the primary antiserum was raised. The cells were incubated overnight with primary antibody and for $120 \mathrm{~min}$ with fluorophore-coupled secondary antibody, with three intermittent washes in a blocking buffer following each incubation. For labeling of filamentous actin, Alexa Fluor 568-phalloidin (Invitrogen) was added at a concentration of $50 \mathrm{ng} / \mathrm{ml}$; for staining nuclei, $4^{\prime}, 6^{\prime}$-diamidino2-phenylindole (Invitrogen) was included at a concentration of $1 \mu \mathrm{g} / \mathrm{ml}$ throughout the secondary-antibody incubation. The cells were mounted in Vectashield and imaged with a laser-scanning confocal microscope (Fluoview FV-1000; Olympus).

Immunoprecipitation. Antibodies were coupled to magnetic M-270 Epoxy Dynabeads (Dynal; Invitrogen) with an optimized version of the protocol suggested by the manufacturer. The beads were washed twice with $1 \mathrm{ml}$ of 100 mu sodium phosphate buffer at $\mathrm{pH} 7.4$, with a 10 min period of shaking between the washes. Antibodies were added at a ratio of $20 \mu \mathrm{g}$ per milligram of beads in $100 \mathrm{~mm}$ sodium phosphate and $1 \mathrm{~m}$ ammonium sulfate, and then incubated overnight on a shaker at $30^{\circ} \mathrm{C}$. The coupled magnetic beads were washed sequentially as follows: in $100 \mathrm{~mm}$ sodium phosphate, $\mathrm{pH} 7.4$; in $100 \mathrm{~mm}$ glycine- $\mathrm{HCl}, \mathrm{pH} 2.5$; in 10 $\mathrm{mm}$ tris(hydroxymethyl)aminomethane, $\mathrm{pH}$ 8.8; in $100 \mathrm{~mm}$ triethylamine; thrice in PBS; twice in PBS containing $0.5 \%$ Triton X-100; and twice in PBS. The beads were then stored at $4^{\circ} \mathrm{C}$ in PBS and $0.02 \%$ sodium azide.

Beads were washed three times with lysis buffer just before use. The cryomilled cochlear powder was thawed and synaptosomes were isolated as described above. Samples were suspended for $30 \mathrm{~min}$ at $4^{\circ} \mathrm{C}$ in a solution containing $110 \mathrm{~mm}$ potassium acetate, $100 \mathrm{~mm} \mathrm{NaCl}, 2$ $\mathrm{mM} \mathrm{MgCl}_{2}, 1 \%$ Igepal-40, 0.1\% Tween 20, 1 mM PMSF, Complete Protease Inhibitor Cocktail (Roche), and $20 \mathrm{~mm}$ HEPES, $\mathrm{pH}$ 7.4. After centrifugation at $15,000 \times g$ for $30 \mathrm{~min}$, the soluble fraction was added to the antibody-coupled magnetic beads. Immunoaffinity purifications were achieved by slow mixing at $4^{\circ} \mathrm{C}$ for $30-120$ $\mathrm{min}$. The magnetic beads were collected using a Dynal magnet (Invitrogen) and washed rapidly approximately six times with the same solution. The isolated protein complex was then eluted from the beads for $20 \mathrm{~min}$ at room temperature in aqueous $500 \mathrm{~mm} \mathrm{NH}_{4} \mathrm{OH}$ and 0.5 mм EDTA. The resulting supernatant was frozen in liquid nitrogen and left to dry overnight by vacuum
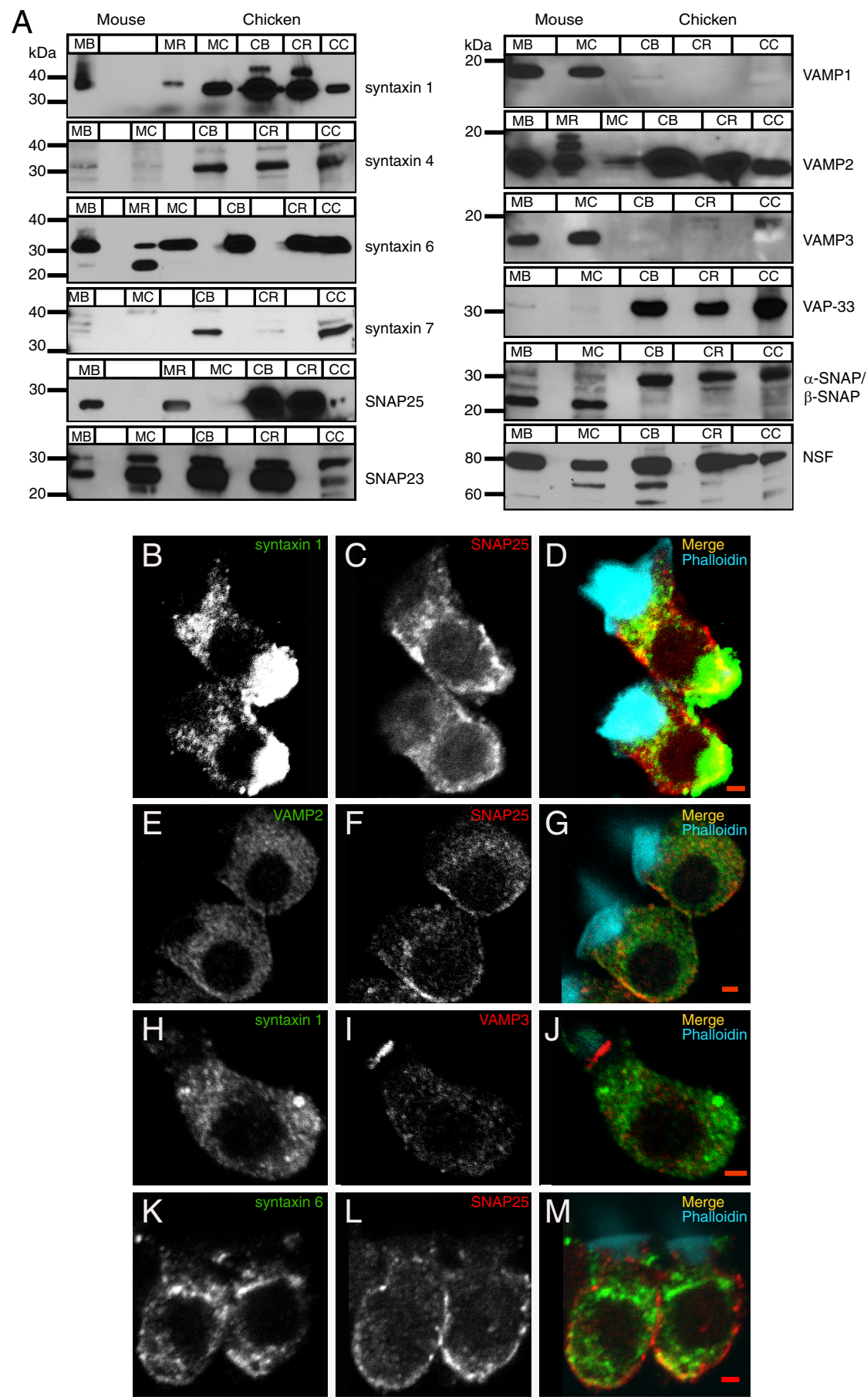

Figure 3. Expression of neuronal and nonneuronal SNARES.A, Immunoblot analysis was conducted on lysates from mouse brains (MB), retinas (MR), and cochleas (MC), and on chicken brains (CB), retinas (CR), and cochleas (CC). We examined the expression of: the neuronal SNAREs syntaxin 1, SNAP25, and VAMP2; the nonneuronal SNAREs syntaxin 4, syntaxin 6, syntaxin 7, SNAP23, VAMP1, VAMP2, and VAMP3; the SNARE-associated protein VAP-33; and the SNARE-dissociation components $\alpha$-SNAP, $\beta$-SNAP, and ATPase NSF. The antisera against syntaxin 6, SNAP23, and ATPase NSF identify the respective proteins in all tissues tested. The antisera against syntaxin 4, syntaxin 7, and VAP-33 labeled only the chicken tissues, whereas the antisera against VAMP1, VAMP3, $\alpha$-SNAP, and $\beta$-SNAP labeled only the mouse tissues. The protein loading in each lane was standardized to a loading control such as $\alpha$-tubulin or GAPDH. $\boldsymbol{B}-\mathbf{M}$, Immunofluorescence localization of SNAREs in single confocal images of isolated chicken hair cells. The labeling with individual antibodies is shown in grayscale, and the merged panels are displayed in color. The hair bundles are labeled cyan with phalloidin. $\boldsymbol{B}-\boldsymbol{D}$, The t-SNARE syntaxin 1 is expressed at the two trafficking hotspots of the hair cell, below the cuticular plate and at the basolateral end. SNAP25 is predominantly associated with the cell membrane. The yellow spots in $\boldsymbol{D}$ show the overlay between the t-SNARES, which can form a binary complex. $\boldsymbol{E}-\boldsymbol{G}$, The vesicle SNARE VAMP2 shows a diffuse pattern of labeling throughout the hair cell exclusive of the hair bundle. There is some colocalization of VAMP2 with SNAP25 at the membrane. $\boldsymbol{H}-\boldsymbol{J}$, Syntaxin 1 occurs diffusely throughout the cytoplasm, whereas VAMP3 is concentrated beneath the hair bundle. $\boldsymbol{K}-\boldsymbol{M}$, Syntaxin 6 and SNAP25 overlap partially in their expression at the hair cell's base. Scale bars: $2 \mu \mathrm{m}$. 
Table 1. Synaptic proteins detected in the cochlea and retina

\begin{tabular}{|c|c|c|}
\hline Proteins identified & Cochlea & Retina \\
\hline \multicolumn{3}{|l|}{ SNARES } \\
\hline$\alpha$-SNAP, $\beta$-SNAP & $M S / I F / I B$ & $\mathrm{MS} / \mathrm{IP} / \mathrm{IB}$ \\
\hline NIPSNAP1 & $\mathrm{IF} / \mathrm{IP}$ & MS \\
\hline NSF & $M S / I F / I B$ & $M S / I P / I B$ \\
\hline SNAP23 & $\mathrm{IF} / \mathrm{IB}$ & $\mathrm{IF} / \mathrm{IB}$ \\
\hline SNAP25 & $\mathrm{IF} / \mathrm{IB}$ & $M S / I P / I B$ \\
\hline Syntaxin 1 & $\mathrm{IF} / \mathrm{IB}$ & $\mathrm{IP} / \mathrm{IB} / \mathrm{MS}$ \\
\hline Syntaxin 3 & IF & MS \\
\hline Syntaxin 4 & IB & IB \\
\hline Syntaxin 6 & $\mathrm{IF} / \mathrm{IB}$ & IB \\
\hline Syntaxin 7 & $\mathrm{MS} / \mathrm{BB}$ & IB \\
\hline Syntaxin 8 & MS & MS \\
\hline Syntaxin 12 & MS & MS \\
\hline VAMP1 & $M S / I F / I B$ & MS \\
\hline VAMP2 & $M S / I F / I B$ & $\mathrm{MS} / \mathrm{IP} / \mathrm{IB}$ \\
\hline VAMP3 & $M S / I F / I B$ & MS \\
\hline VAMP7 & $\mathrm{MS} / \mathrm{B}$ & - \\
\hline VAP-33 & $\mathrm{MS} / \mathrm{B}$ & $M S / I B$ \\
\hline VAP-B & $M S / I B$ & $M S / I B$ \\
\hline \multicolumn{3}{|l|}{ Exocytosis and regulation } \\
\hline Annexins $2,4,5,6,8,11$ & $\mathrm{MS} / \mathrm{PP}$ & MS \\
\hline CaMKII & IF & $M S / I P$ \\
\hline CASK & IB & IB \\
\hline Complexins 1, 2 & Absent & Absent \\
\hline Complexins 3,4 & - & - \\
\hline CSP & $\mathrm{MS} / \mathrm{BB}$ & $\mathrm{MS} / \mathrm{IP} / \mathrm{IB}$ \\
\hline GLAST1 & MS & $M S / I P$ \\
\hline $\mathrm{H}^{+}, \mathrm{K}^{+}$-ATPase & $M S / I P$ & $M S / I P$ \\
\hline KCNQ1 & MS & MS \\
\hline Mint1 & Absent & - \\
\hline Munc13-1 & Absent & IB \\
\hline Munc18 & $M S / I F / I P / I B$ & $\mathrm{MS} / \mathrm{IP} / \mathrm{IB}$ \\
\hline $\mathrm{Na}^{+}, \mathrm{K}^{+}$-ATPase & $\mathrm{MS} / \mathrm{IP} / \mathrm{IB}$ & $M S / I P / I B$ \\
\hline NCAM1 & - & MS \\
\hline Otoferlin & $\mathrm{MS} / \mathrm{IF}$ & Absent \\
\hline PMCA2 & MS & MS \\
\hline Rab3 & $M S / I F / I B$ & $M S / I P / I B$ \\
\hline Rab8 & $\mathbb{P}$ & MS \\
\hline Rabphilin & $\mathrm{MS} / \mathrm{IF}$ & - \\
\hline Reticulons 1, 3, 4 & MS & $M S / I P$ \\
\hline SV2A, SV2B & Absent & MS \\
\hline Synapsin 1 & Absent & Absent \\
\hline Synapsin 2a & Absent & Absent \\
\hline Synaptophysins 1,2 & Absent & $M S / I P / I B$ \\
\hline Synaptotagmin 1,2 & Absent & $M S / I P / I B$ \\
\hline Tomosyn & Absent & IB \\
\hline V-ATPase & $M S / I P$ & $M S / I P$ \\
\hline VCP & $M S / I F / I P / I B$ & $M S / I P / I B$ \\
\hline VGLUT3 & $\mathrm{IF} / \mathrm{IB}$ & $\mathbb{I P}$ \\
\hline Visinin & - & $\mathbb{P}$ \\
\hline \multicolumn{3}{|l|}{ Endocytosis and regulation } \\
\hline AP-1 & MS & $M S / I P$ \\
\hline AP180 & MS & - \\
\hline AP-2 & MS & $M S / I P$ \\
\hline AP-3 & - & $\mathbb{I P}$ \\
\hline Clathrin heavy chain & $M S / I F / I P / I B$ & $M S / I P / I B$ \\
\hline Dynamin & $M S / I F / I P / I B$ & MS/IB \\
\hline Endophilin & $\mathrm{IF} / \mathrm{IB}$ & IB \\
\hline LIN-7 & - & $M S / I P$ \\
\hline SCAMP1 & $\mathrm{MS} / \mathrm{IB}$ & - \\
\hline Synaptojanin & $\mathrm{MS} / \mathrm{BB}$ & IB \\
\hline \multicolumn{3}{|l|}{ Cytoskeleton } \\
\hline$\alpha$-Actinin & MS & $\mathbb{I P}$ \\
\hline Actins $\alpha, \beta$ & $\mathrm{MS} / \mathrm{IF} / \mathrm{IP} / \mathrm{IB}$ & $M S / I P / I B$ \\
\hline$\beta$-Catenin & $\mathrm{IF} / \mathrm{IB}$ & $\begin{array}{c}\mathrm{MS} / \mathrm{IP} / \mathrm{IB} \\
\text { continues.) }\end{array}$ \\
\hline
\end{tabular}

Table 1. Continued

\begin{tabular}{|c|c|c|}
\hline Proteins identified & Cochlea & Retina \\
\hline Dynein light chain & MS & MS/IP \\
\hline Gelsolin & $M S / I P$ & MS \\
\hline Internexin- $\alpha$ & $\mathbb{P}$ & MS/IP \\
\hline MAP1B, MAP4 & - & $M S / I P$ \\
\hline MYH9 & $M S / I F / I P / I B$ & $M S / I B$ \\
\hline Myosin-1a & $\mathbb{P}$ & MS \\
\hline Myosin-2 & $M S / I P$ & $\mathbb{I P}$ \\
\hline Myosin 5 & MS & - \\
\hline Myosin-6 & $M S / I F / I B$ & MS \\
\hline $\mathrm{N}$-cadherin & IF/IB & IB \\
\hline Neuroligin & IB & IB \\
\hline NF160 & $\mathrm{MS} / \mathrm{IF} / \mathrm{IB}$ & $M S / I P / I B$ \\
\hline NF200 & $M S / I F / I P / I B$ & $M S / I B$ \\
\hline NF68 & $\mathrm{IF} / \mathrm{IB}$ & $M S / I P / I B$ \\
\hline Spectrins $\alpha, \beta$ & $M S / I F / I P / I B$ & IB \\
\hline Thy1 & MS & MS \\
\hline Tropomyosin & MS/IP & MS \\
\hline Tubulins $\alpha, \beta$ & $\mathrm{MS} / \mathrm{IF} / \mathrm{IP} / \mathrm{IB}$ & $M S / I P / I B$ \\
\hline Villin & $M S / I P$ & MS \\
\hline Vimentin & IF & $M S / I P$ \\
\hline \multicolumn{3}{|l|}{ Synaptic ribbon } \\
\hline Bassoon & $\mathrm{IB} / \mathrm{IP}$ & MS \\
\hline CtBP1 & IF/IP/IB & IB \\
\hline $\mathrm{CtBP2}$ & $\mathrm{IF} / \mathrm{IP} / \mathrm{IB}$ & IP/IB \\
\hline ERC2 & IB & IB \\
\hline KIF3A & $\mathrm{IF} / \mathrm{IB}$ & IB \\
\hline Piccolo & IB/MS & IB \\
\hline Ribeye & $\mathrm{IF} / \mathrm{IP} / \mathrm{IB}$ & $\mathbb{I P} / \mid \mathrm{B}$ \\
\hline RIM1 & $\mathrm{IB}$ & IB \\
\hline RIM2 & IB & IB \\
\hline
\end{tabular}

The codes denote protein identification by MS, immunofluorescence labeling of dissociated hair cells (IF), immunoprecipitation with ribeye antibodies (IP), or immunoblot analysis (IB). "Absent" denotes a lack of expression detectable by any of the four methods and a dash means that a determination was not done.

centrifugation. The pellet was resuspended in sample buffer and subjected to SDS-PAGE and LC-MS/MS analysis.

Ribeye was immunoprecipitated with either of two reagents. We used a murine monoclonal antibody (BD Transduction Laboratories) against the $\mathrm{C}$-terminal $\mathrm{B}$-domain of $\mathrm{CtBP} 2$, which is shared by ribeye. A rabbit polyclonal antiserum was raised against the purified $\mathrm{N}$-terminal A-domain of ribeye. For this purpose, a cDNA encoding the A-domain of chicken ribeye (amino acids $1-553$ ) was cloned in a $\mathrm{pET}_{28 \mathrm{a}^{+}}$vector (Novagen) and transformed into Escherichia coli strain BL21 (DE3). Cultures in logarithmic phase, at an optical density at $600 \mathrm{~nm}$ of $0.6-0.8$, were induced with $0.5 \mathrm{~mm}$ isopropyl- $\beta$-D-thiogalactopyranoside for protein expression overnight at $16^{\circ} \mathrm{C}$. The soluble protein was purified through its hexahistidine tag by affinity chromatography on nickel nitrilotriacetic acid beads (Qiagen).

Immunoelectron microscopy. Dissected cochleas were fixed overnight with $4 \%$ paraformaldehyde and $0.1 \%$ glutaraldehyde in $\mathrm{PBS}$ at $\mathrm{pH}$ 7.4. The tissue was treated with $0.5 \% \mathrm{H}_{2} \mathrm{O}_{2}$ and $0.1 \%$ sodium borohydride; blocked with $3 \%$ bovine serum albumin, $0.1 \%$ cold-water fish-skin gelatin, and $0.1 \%$ saponin; and incubated with antiserum against ribeye, CtBP1, CtBP2, Rab3, or syntaxin 1. The preparation was then incubated with biotinylated secondary antibody, and the immunocomplex was visualized by the avidin-biotin-peroxidase complex method (Vector Laboratories) with diaminobenzidine as a chromogen and silver enhancement (Galvin et al., 1999). After postfixation with 1\% osmium tetroxide, the tissue was dehydrated through a graded series of ethanol concentrations and embedded in EMBed812. Thin sections were cut and examined under an electron microscope (Tecnai Spirit G2; FEI).

\section{Results}

Our objective was to isolate and characterize the synaptic components of cochlear hair cells by using biochemical purification of presynaptic material and immunoprecipitation of ribeye- 
containing protein complexes. Proteins isolated in this manner were identified by mass spectrometry. A subset of these proteins was selected to analyze their site-specific localization by immunocytochemical examination of isolated hair cells, and their size was analyzed by immunoblotting on cochlear lysates.

\section{Fractionation of presynaptic proteins from ribbon synapses}

To isolate presynaptic proteins from chicken cochleas, we began by using a standard purification protocol used for synaptosomes from the CSN. Because we needed large amounts of tissue, as was established for synaptosome isolation in the CNS, this constituted a major experimental effort. As indicated in the flowchart (Fig. 1A), the presynaptic material was first purified by differential centrifugation and then by density-gradient centrifugation based on sedimentation velocity. The cochlear synaptosome preparations may have included vesicle proteins from the attached afferent and efferent terminals and from other cell types (Corwin and Warchol, 1991) in addition to hair cells.

Immunoblot analysis of the samples from the sequential steps of differential and gradient centrifugation disclosed the presence of the vesicle protein VAMP2 (synaptobrevin 2) and ribeye in the sedimented pellet of the sucrose gradient from both cochlear and retinal fractions (Fig. $1 B)$. Electron-microscopic analysis of this sample showed the labeling for ribeye in the electron-dense structures (supplemental Fig. 1, available at www.jneurosci.org as supplemental material). We therefore suggest that this fraction comprises synaptic ribbons and some tethered vesicles. The fractionated proteins were collected, separated by denaturing-gel electrophoresis (Fig. 2A, $B$ ), and subjected to LC-MS/MS.

The cochlea and retina both expressed numerous proteins in several functional classes (Fig. 2C,D; supplemental Tables 2, 3, available at www.jneurosci.org as supplemental material). As expected, we identified many proteins that are expressed in the presynaptic region, which we classify as vesicle and membrane transport proteins, accounting for $\sim 35 \%$ of the total in each organ. Among these we found in both organs a significant number of proteins that effect or modulate synaptic exocytosis: SNAREs and SNARE regulators; endocytotic components; proteins involved in intracellular membrane trafficking; ion channels, transporters, and pumps; small GTPases and their regulators; and $\mathrm{Ca}^{2+}$ and lipid-binding proteins (supplemental Tables 2, 3, available at www.jneurosci.org as supplemental material). We also isolated molecular chaperones and regulators of cytoskeletal dynamics, both of which are essential for vesicle transport.
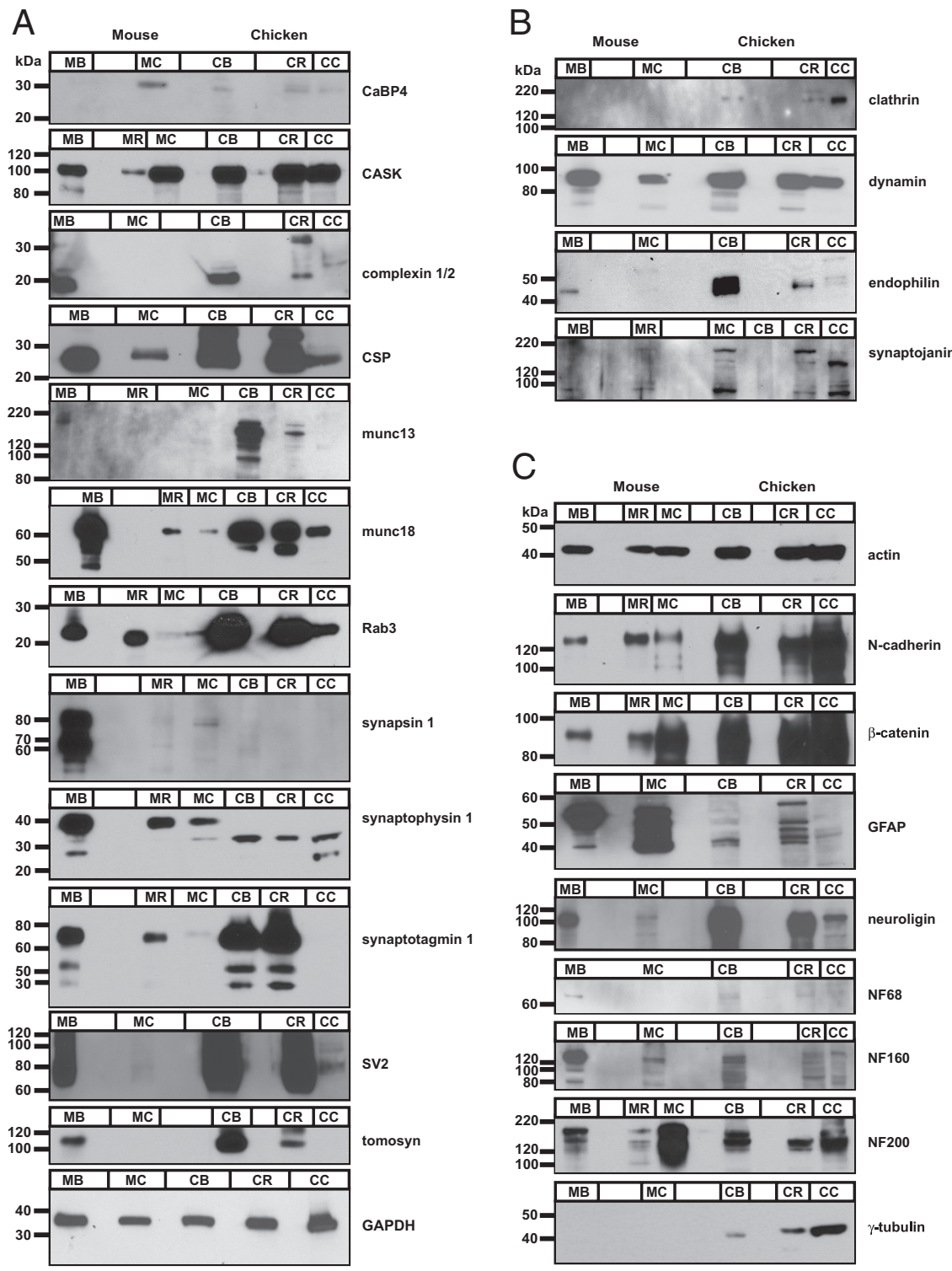

Figure 4. Expression studies of exocytotic, endocytotic, and cytoskeletal proteins. Immunoblot analysis was conducted on lysates from mouse brains (MB), retinas (MR), and cochleas (MC), and from chicken brains (CB), retinas (CR), and cochleas (CC). Some of the antisera, such as those against synapsin 1 and synaptophysin 1, recognized only mouse lysates; the antisera against clathrin, neurofilament-L (NF68), and $\gamma$-tubulin recognized only chicken material. The antiserum against synaptophysin 1 recognized a protein of a size other than that expected for synaptophysins. A, Analysis of proteins involved in exocytosis documents that munc18, the multidomain scaffolding protein CASK, and the small GTPase Rab3 are expressed in all tissues tested. We also observed wide expression of the $\mathrm{Ca}^{2+}$-binding protein CaBP4 and CSP. The vesicle-priming regulators complexins 1 and 2 , munc13-1, and tomosyn were excluded from hair-cell lysates. Although cochlear lysates from the chicken lacked synaptotagmin 1 , we observed faint signals for synapsin 1,SV2, and synaptotagmin 1 in murine cochlear samples, possibly because of contamination from respectively afferent and efferent terminals. $\boldsymbol{B}$, The endocytotic proteins dynamin, clathrin, endophilin, and synaptojanin occur in the cochlea. C, Cochlear lysates contained actin, tubulins, and neurofilament proteins as well as adhesion proteins such as $\mathrm{N}$-cadherin, $\beta$-catenin, and neuroligin.

Apart from synaptic proteins, we identified in both tissues an abundance of enzymes involved in glycolysis, the citric acid cycle, and oxidative phosphorylation. We also observed proteins from intracellular organelles such as the endoplasmic reticulum, Golgi apparatus, peroxisomes, and mitochondria. A few nuclear proteins and some cochlea- and retina-specific proteins were enriched in our preparations.

Synaptosomes purified from the synapses in the CNS fractionate at the 200-400 mm sucrose interface (Takamori et al., 2006). Immunoblotting of retinal and cochlear fractions revealed 
relatively large amounts of the vesicle-associated membrane protein VAMP2 at this interface, in addition to the sucrose pellet described above, and some expression in the other fractions (Fig. $1 B)$. Immunoelectron microscopy confirmed the presence of VAMP2 at the 200-400 mM sucrose interface in the cochlea (supplemental Fig. 2, available at www.jneurosci.org as supplemental material). This difference in distribution could be caused by the presence of the ribbon. Hence, these various sucrose-gradient samples originating from the cochleas were subjected to tandem mass spectrometry to analyze the fractionation pattern of the various synaptic proteins (supplemental Tables 4-6, available at www.jneurosci.org as supplemental material). We also analyzed the $47,000 \times g$ differential centrifugation pellet (supplemental Table 7, available at www.jneurosci.org as supplemental material), since we observed ribeye expression in immunoblotting. Interestingly, these results indicated also a broad distribution for the cochlea-specific protein otoferlin in the $400-600 \mathrm{~mm}$ and 600-800 mM sucrose interfaces and in the pellet (supplemental Tables 4-6, available at www.jneurosci.org as supplemental material).

Although we identified a large number of proteins during the fractionation of presynaptic material, we set out to study in detail the expression analysis of the crucial SNARE molecules, their regulators (Südhof and Rothman, 2009), and the various exocytotic, endocytotic, cytoskeletal, and other proteins that are involved in regulating neurotransmitter release (Garner et al., 2000).

\section{Expression analysis of SNARE proteins}

A key event in membrane fusion and neurotransmitter release is the association of the V-SNARE VAMP2 in the vesicle membrane with the target SNAREs (t-SNAREs) syntaxin 1 and SNAP25 in the target plasmalemma. In our cochlear fractionation experiments, we isolated VAMP2 and other SNAREs such as syntaxin 7 , syntaxin 8 , syntaxin 12 , VAMP3, and tetanus neurotoxin-insensitive VAMP (TI-VAMP, VAMP7). Synaptic fractionation of the retina revealed syntaxin 3, SNAP25, VAMP2, and the endocytotic proteins syntaxin 8 and VAMP3. NSF, $\alpha$-SNAP, $\beta$-SNAP, and $\gamma$-SNAP were found in both tissues (supplemental Tables 2, 3, available at www.jneurosci.org as supplemental material).

To validate the expression of SNAREs in the cochlea, we measured the expression of proteins, including some not identified in the proteomic analysis, by immunoblotting of cochlear lysates. We compared the results with those of brain and retinal lysates from the mouse and chicken. We documented the expression of neuronal SNAREs, albeit with only a weak signal for SNAP25 in the cochlea, as well as of nonneuronal SNAREs and the SNAREdissociation proteins NSF and $\alpha$-SNAP or $\beta$-SNAP (Fig. $3 A$ ).

By immunofluorescence labeling of isolated chicken hair cells, we inquired whether the SNAREs occur in the synaptic portions of hair cells. Like VGLUT3, VAMP2 should be distributed throughout the cytosol (Obholzer et al., 2008; Seal et al., 2008). SNAP25 and syntaxin 1 would be expected to occur at the plasma membrane, potentially clustering at the ribbon sites. We observed syntaxin 1 labeling at both the bases and apices of hair cells (Fig. 3B-D). SNAP25 labeling, on the other hand, was concentrated along the plasmalemma. Although both immunoreactivities display broad distributions, we observed overlap in the labeling patterns of these two proteins especially at the base of the hair cell (Fig. 3D). Note that we also observe syntaxin 1 labeling outside the cell, possibly from the residual efferent terminals (Fig. $3 B-D)$. VAMP2 was distributed diffusely throughout the hair cell exclusive of the hair bundle (Fig. $3 E-G$ ). The endosomal SNARE
A

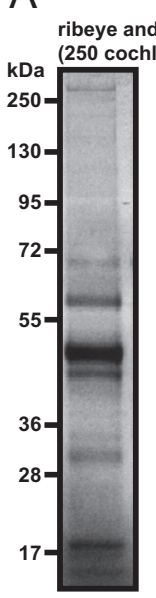

$B$
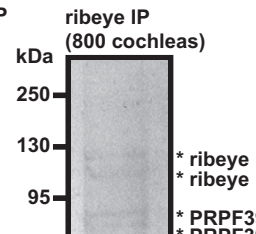

72- $\quad$ *PRPF39
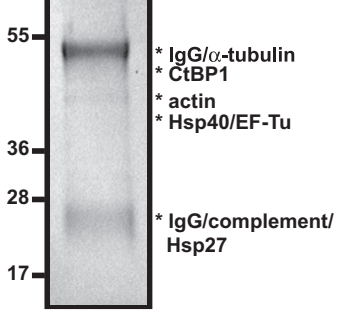

Mouse

$D_{k D a}$
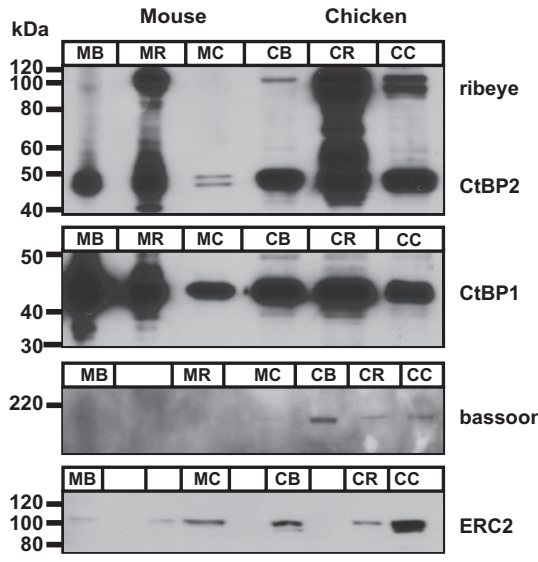

ERC2

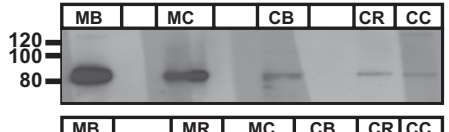

KIF3A
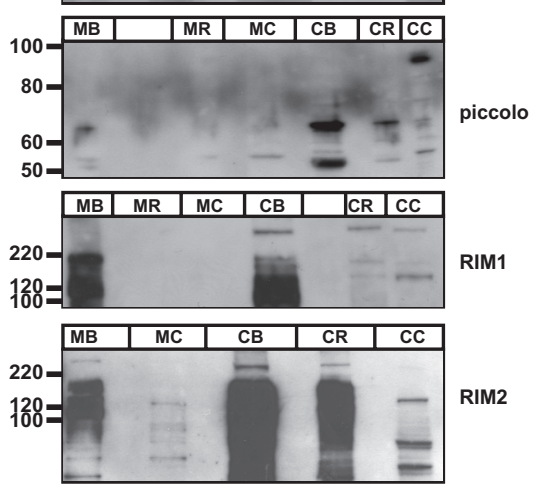

Figure 5. Purification of synaptic ribbons. $A-C$, Coomassie-stained SDS-PAGE bands from coimmunoprecipitation experiments and protein identification by LC-MS/MS. $A, A n$ immunoprecipitation on 250 cochleas with B-domain antibodies captures $\mathrm{CtBP2}$, ribeye, and a large number of other proteins (Table 2). $\boldsymbol{B}$, Use of the A-domain antiserum on a lysate from 800 cochleas isolated only a modest number of proteins that are labeled alongside the bands in the gel. $C$, Use of the A-domain antiserum on synaptosomes prepared from five bovine retinas revealed a large number of vesicle proteins (Table 3). $\boldsymbol{D}$, Immunoblot analysis showed the expression of ribbon proteins and ribbon-associated molecules in lysates from mouse brains (MB), retinas (MR), and cochleas (MC), and from chicken brains (CB), retinas (CR), and cochleas (CC). The core ribbon proteins of the $\mathrm{CtBP}$ family, CtBP1, CtBP2, and ribeye, are abundantly expressed. Cochlear lysates also included the known ribbon-associated proteins ERC2, KIF3A, RIM1, RIM2, bassoon, and piccolo. 
Table 2. Proteins isolated from chicken cochleas with monoclonal antibodies against the B-domain (CtBP2 domain) of ribeye

\begin{tabular}{|c|c|c|c|c|c|}
\hline $\begin{array}{l}\text { Proteins expressed in the } \\
\text { presynaptic region }\end{array}$ & Enzymes & Chaperones & Cytoskeleton & $\begin{array}{l}\text { Nuclear and transcription } \\
\text { proteins }\end{array}$ & Others \\
\hline Membrane transport and SNARE & Glycolytic enzymes & Hsp70 & Actins $\alpha, \beta$ & Histones $\mathrm{H} 2 \mathrm{~A}, \mathrm{H} 2 \mathrm{~B}, \mathrm{H} 4$ & Cochlin \\
\hline proteins & VDAC2 & $\mathrm{TCP} 1$ & Dystonin isoform & $\mathrm{EF}-\mathrm{Tu}$ & Furin \\
\hline Annexins 1, 2, 5 & GAPDH & & Gelsolin & $\mathrm{EF}-1 \alpha$ & Major vault protein \\
\hline Bassoon & ATP synthase & & Nexilin & Nuclear CAMBP & Myelin basic protein \\
\hline CtBP1 & Pyruvate kinase enolase & & Tubulins $\alpha, \beta$ & Prohibitin & Serum albumin \\
\hline $\mathrm{CtBP2}$ & Mitochondria & & NF200 & & SOUL heme binding protein \\
\hline $\mathrm{H}^{+}, \mathrm{K}^{+}$-ATPase & Creatine kinase & & NF60 & & $\epsilon$-Globin \\
\hline Munc18 & SLC25A4 & & MYH9 & & $\mathrm{G}$-protein $\beta$ \\
\hline $\mathrm{Na}^{+}, \mathrm{K}^{+}$-ATPase & Glutamate metabolism & & Myosin regulatory light chain & & \\
\hline NIPSNAP1 & GRIP1 & & Myosin-1 & & \\
\hline Ribeye & Glutamine synthetase & & Tropomyosin 4 & & \\
\hline VCP & Sacharopine dehydrogenase & & $\gamma$-Catenin & & \\
\hline V-ATPase & & & Heparin sulphate proteoglycan core & & \\
\hline S100 calcium binding protein A8 & & & protein & & \\
\hline Calgranulin & & & Syndecan & & \\
\hline Calmodulin-like 5 & & & Type II collagen $\alpha$ & & \\
\hline Endocytic & & & Fibronectin I & & \\
\hline \multicolumn{6}{|l|}{ Clathrin heavy chain } \\
\hline \multicolumn{6}{|l|}{ Dynamin } \\
\hline \multicolumn{6}{|l|}{ Intracellular trafficking } \\
\hline \multicolumn{6}{|l|}{$\beta^{\prime}$ COP (COPI coat) } \\
\hline \multicolumn{6}{|l|}{ Rabs $1,8,15,10,35$} \\
\hline Sec13-like (COPII coat) & & & & & \\
\hline
\end{tabular}

VAMP3 occurred just below the base of the hair bundle, creating a necklace-like pattern of labeling (Fig. $3 H-J)$. Syntaxin 6 localized to the apical and basolateral regions (Fig. $3 K-M$ ), the two proposed areas of membrane trafficking in the hair cell. Table 1 provides a detailed comparative analysis of the expression of synaptic proteins identified from the cochlea and retina by mass spectrometry after fractionation and immunoprecipitation and those that were analyzed further by immunocytochemistry and immunoblotting.

\section{Analysis of proteins expressed in the presynaptic region}

In our fractionations of the cochlea and retina, we isolated several proteins that are involved in the steps leading to synaptic-vesicle release and regulation (Table 1 ; supplemental Tables 2, 3, available at www.jneurosci.org as supplemental material). Many were expressed in both the cochlea and retina, such as CaMKII, munc18, NIPSNAP1, Rab3, Thy1, VAMP-associated proteins (VAP-33 and VAP-B), neural cell-adhesion molecule 1 (NCAM1), VCP (p97 ATPase), vacuolar ATPase, $\mathrm{H}^{+}, \mathrm{K}^{+}$-ATPase, $\mathrm{Na}^{+}, \mathrm{K}^{+}$-ATPase, plasma-membrane $\mathrm{Ca}^{2+}$ ATPase 2 (PMCA2), excitatory aminoacid transporter 1 (EAAT1, GLAST1), and $\mathrm{K}^{+}$channel KCNQ1. The $\mathrm{Ca}^{2+}$ - and phospholipid-binding annexins and the endoplasmic reticulum-associated reticulon family of trafficking proteins were particularly abundant in both the tissues.

To validate the expression of the identified molecules, and to confirm the expression of some synaptic proteins that were not identified in the proteomic analysis, we conducted immunoblotting experiments. We observed in both tissues the multidomain scaffolding protein CASK, the vesicle-priming protein munc18, the small GTPase Rab3, the $\mathrm{Ca}^{2+}$-binding protein CaBP4, and CSP (Fig. 4A). Also present in the cochlea were the endocytotic proteins AP-1, AP-2, clathrin, dynamin, endophilin, secretory-associated membrane protein 1 (SCAMP1), and synaptojanin (Fig. $4 B$ ). Both the cochlear and the retinal fractions and immunoblots on tissue lysates displayed high expression levels of cytoskeletal proteins such as actin, actin-binding proteins, tubulin, dynein light chain, and neurofil- amins, as well as of adhesion proteins such as $\mathrm{N}$-cadherin, $\beta$-catenin, and neuroligin (Fig. 4C). Both the tissues contained large amounts of MYH9, $\alpha$-spectrin, and $\beta$-spectrin.

Fractionation revealed notable differences between the protein complements of the cochlea and retina. Otoferlin was one of the most abundant synaptic proteins isolated from the cochlea but was absent from the retina. Synapsins 1 and 2, synaptophysin 1 , synaptogyrin, synaptoporin, and SV2s were not apparent in the cochlear fractions (Table 1). Except for synapsins, all of these vesicle proteins were isolated from the retinal fractions. However, faint immunoblot signals for synaptophysin 1 , synapsin 1 , and SV2 were observed in cochlear tissue lysates (Fig. $4 A$ ), suggesting that the labeling stems from residual afferent and efferent terminals in our preparation. Consistent with this explanation, we observed no specific labeling when we sought these proteins by immunocytochemistry of isolated hair cells (data not shown). Fractionation experiments and immunoblots on tissue lysates from the cochlea confirmed the absence of the regulatory proteins synaptotagmin 1, complexins 1 and 2, munc13-1, and tomosyn, all of which were expressed in brain and retinal lysates (Fig. 4A). Some synaptic proteins were found only in the cochlea: the $\mathrm{Ca}^{2+}$ sensor otoferlin, $\mathrm{Ca}^{2+}$-binding synaptotagmin 7 , the regulatory proteins $\alpha$-synuclein and syntaphilin, the cytomatrix protein piccolo, and the endocytotic components synaptojanin 2 and SCAMP1 (Table 1; supplemental Tables 2, 3, available at www. jneurosci.org as supplemental material).

We conclude that many synaptic proteins are conserved between ribbon synapses and conventional synapses. Several important regulatory proteins are absent from ribbon synapses, though, and we observe that the composition of ribbon synapses in hair cells differs from that in the retina.

\section{Coimmunoprecipitation of ribeye-containing protein complexes}

To investigate the molecular constitution of the synaptic ribbon, we purified ribeye and its binding partners by co-immuno- 
Table 3. Proteins isolated from bovine retinas with a polyclonal antiserum against the A-domain of ribeye

\begin{tabular}{|c|c|c|c|c|c|}
\hline $\begin{array}{l}\text { Proteins expressed in the presynatic } \\
\text { region }\end{array}$ & Enzymes & Chaperones & Cytoskeleton & $\begin{array}{l}\text { Nuclear and transcription } \\
\text { proteins }\end{array}$ & Others \\
\hline Membrane-transport and SNARE & Glycolytic enzymes & Hsp1 & Actins $\alpha, \beta$ & hnRNP A2/B1 & Blue-sensitive opsin \\
\hline proteins & GAPDH & Hsp40 & Dihydropyrimi-dinase-like 2 & hnRNP K & G proteins $\alpha, \beta$ \\
\hline Annexin 6 & Glucose phosphate isomerase & Hsp27 & Matrin 3 & snRNP SmD1 & Peripherin \\
\hline CaMKII & Hexokinase 1 & Hsp70 & Spectrin $\alpha$ & Histone $\mathrm{H} 2 \mathrm{~A}, \mathrm{H} 4$ & Phosducin \\
\hline CSP & Phosphoglycerate kinase & Hsp90 & Tubulins $\alpha, \beta$ & Nucleoporin & Retinal GPCR \\
\hline munc18-1 & Phosphoglycerate mutase & ER chaperones & NF68 & Cohesin1 homolog & Retinaldehyde-binding \\
\hline $\mathrm{Na}^{+}, \mathrm{K}^{+}$-ATPase & Pyruvate kinase 3 & Calnexin & NF160 & Prohibitin 2 & protein \\
\hline NCAM1 & Triose-phosphate isomerase & Ribophorin & GFAP & & Retinol-binding protein \\
\hline NSF & $\alpha$ Enolase & & Internexin- $\alpha$ & & Rhodopsin \\
\hline Rab3a, 3B, 3D & Mitochondria and citric acid cycle & & Fibronectin I & & Rod outer segment-binding \\
\hline Ribeye & Aconitase 2 & & Vimentin $1 / 2$ & & protein \\
\hline SNAP25 & ATP synthase & & & & S-arrestin \\
\hline Synaptophysin 1 & Creatine kinase & & & & Transducins $\alpha, \beta$ \\
\hline Synaptotagmin 1 & Cytochrome c oxidase & & & & Ubiquitin \\
\hline VAMP2 & F1-ATPase & & & & Erythrocytic membrane \\
\hline VAP-33 & Lactate dehydrogenase & & & & protein band 4.1-like 2 \\
\hline V-ATPase, lysosomal & Malate dehydrogenase & & & & Haemoglobin $\beta$ \\
\hline V-ATPase & Mitofilin & & & & Serum albumin precursor \\
\hline VCP & NADH dehydrogenase & & & & Basigin \\
\hline SLCA1 (GLAST) & Oxoglutarate carrier & & & & Glutathione transferase \\
\hline Unc-51-like kinase 2 & Phosphofructokinase & & & & cGMP-specific \\
\hline Endocytic & SLC25A4, SLC25A5, SLC25A6, & & & & phosphodiesterase \\
\hline AP-1 & SLC25A12 & & & & $14-3-3 \zeta$ \\
\hline AP-2 & SLC13 & & & & \\
\hline Clathrin heavy chain & Succinate dehydrogenase & & & & \\
\hline Intracellular trafficking & transketolase & & & & \\
\hline Rabs 1, 4, 15, 33, 35, 37 & Ubiquinone-cytochrome c reductase & & & & \\
\hline Rap1 & VDACs $1,2,3$ & & & & \\
\hline Reticulons 1, 3A, 4 & Glutamate metabolism & & & & \\
\hline Brain-abundant membrane-attached & Glutamine synthetase & & & & \\
\hline protein1 & Glutamine oxaloacetic transaminase & & & & \\
\hline Lipid binding & Aspartate aminotransferase & & & & \\
\hline Apolipoprotein 0 & & & & & \\
\hline Fatty acid synthase & & & & & \\
\hline PEBP1 & & & & & \\
\hline
\end{tabular}

precipitation with either monoclonal antibodies directed against the B-domain (CtBP2 domain) or a polyclonal antiserum against the A-domain of ribeye (Fig. 5). Immmunoblots indicate specific immunoprecipitation of both ribeye and CtBP2 in the B-domain immunoprecipitation (supplemental Fig. $3 A$, available at www. jneurosci.org as supplemental material) but of ribeye alone in the A-domain immunoprecipitation (supplemental Fig. 3B, available at www.jneurosci.org as supplemental material). Although we cannot yet confirm that we have purified intact synaptic ribbons, we have successfully purified ribeye-containing protein complexes and further examined the associated proteins. Immunoprecipitation with $\mathrm{B}$-domain antibodies isolated a large number of proteins (Fig. 5A, Table 2). In contrast, the A-domain antiserum yielded only a small complement of proteins (Fig. $5 B$ ). From these experiments, we inferred that the A-domain antiserum is a more specific reagent than the B-domain antibody.

Although we used 800 cochleas, we purified only a small quantity of ribeye and its interacting proteins with the A-domain antiserum. We therefore elected to use the bovine retina as a source of greater amounts of ribeye and its partners. From this organ we purified a large number of synaptic proteins, including synaptotagmin 1, synaptophysin 1, VAMP2, CSP, Rab3a, Rab3B, and Rab3D, SNAP25, munc18-1, NSF, AP-1, clathrin heavy chain, CaMKII, and vacuolar ATPase (Fig. 5C, Table 3). Isolation of vesicle proteins indicated that the ribbons remained intact and that the synaptic vesicles were attached to the ribbon during our purification procedure. Several cytoskeletal proteins such as actin, tubulin, spectrin, neurofilament-H (NF200), neurofilament-M (NF160), and $\alpha$-internexin were also identified. We did not, however, consistently isolate the previously described ribbon-associated proteins RIM1, piccolo, KIF3A, ERC2, and bassoon (Fig. 5B, Tables 2, 3). Even in our fractionation experiments, we isolated piccolo only from the cochlea and bassoon only from the retina (Table 1). We therefore tested for the presence of these proteins in cochlear lysates by immunoblotting and compared these results with those obtained from brain and retinal lysates (Fig. 5D). As expected, we observed expression of all the ribbon-associated proteins in every examined organ with the exception of ribeye in the brain.

We next examined the localization of the isolated proteins within hair cells to determine whether they colocalized with synaptic ribbons. Many of the vesicle transport proteins were highly expressed in the basolateral portions of hair cells. We observed only partial colocalization of the ribbons with the SNAREs, SNARE-dissociation ATPase NSF (supplemental Fig. 4, available at www.jneurosci.org as supplemental material), the endocytotic proteins clathrin and endophilin (supplemental Fig. 5, available at www.jneurosci.org as supplemental material), and cytoskeletal 

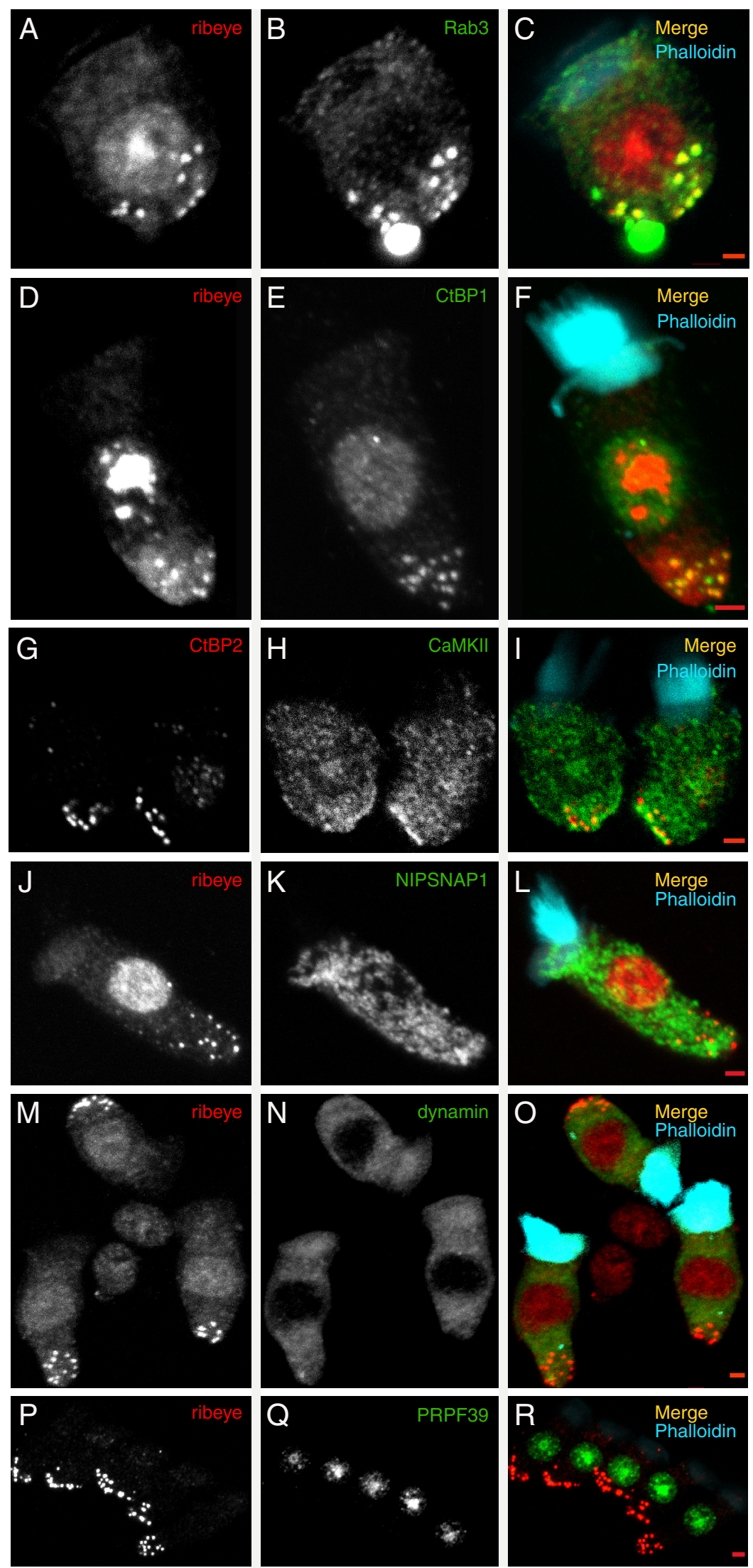

proteins such as actin, tubulin, neurofilaments, and spectrin (supplemental Fig. 6, available at www.jneurosci.org as supplemental material). Signaling proteins such as GAPDH and 14-3-3 and the trafficking proteins $\beta$ subunit of coatomer protein $(\beta$-COP) and Sec13, which form the COP I and COP II coats, respectively, were highly expressed throughout the hair cell. Three proteins colocalized with the ribbons. Rab3, a small GTPase implicated in diverse aspects of vesicle docking, priming, and fusion (Südhof, 1997; Ng and Tang, 2008), labeled the ribbons (Fig. 6A-C). Rab3 labeling was also observed at the plasma membrane, perhaps because of the residual afferent terminals attached to the isolated hair cells. CtBP1, a member of the CtBP family, was associated with ribbons (Fig. 6D,E). We additionally observed partial colocalization with ribbons of phosphorylated CaMKII, a protein that is widely expressed in hair cells (Fig. 6G-I).

Because several proteins were repeatedly isolated in different experiments, we tested for their expression in hair cells. NIPSNAP1, a nonneuronal SNAP25-like protein, showed strong labeling throughout the hair cell (Fig. 6J-L). The endocytotic protein dynamin was also diffusely distributed. We conclude that these proteins do not colocalize with ribbons, but are highly expressed in hair cells (Fig. 6M-O). We tested the localization of the pre-mRNA processing factor homolog PRPF39, which was isolated from cochlear homogenates with the A-domain antiserum. Although as expected strong labeling was apparent in the nucleus (Fig. $6 P-R$ ), no colocalization with ribbons was observed.

We performed immunoelectron microscopy to analyze at a greater resolution the spatial expression of CtBP2, ribeye, Rab3, and CtBP1 (Fig. 7A-D) at the synaptic junctions of hair cells. We observed a high density of labeling for ribeye, CtBP2, and $\mathrm{CtBP} 1$ in synaptic ribbons, with the CtBP1 signal limited to the ribbons' surfaces. In contrast, Rab3 staining was observed on the vesicles and, unexpectedly, also within the ribbons.

Figure 6. Analysis of ribeye-interacting molecules by immunofluorescence microscopy on isolated chicken hair cells. Ribeye throughout the cytoplasm but is not significantly present was immunolabeled with the A-domain antiserum and CtBP2 with B-domain antibodies, both of which are shown as red in the The protein PRPF39, which is identified in cochlear lysates merged images; the hair bundles were labeled with phalloidin and are depicted in cyan. $\boldsymbol{A}-\boldsymbol{C}$, Synaptic ribbons are uniformly by the A-domain antiserum, is confined to the nucleus. labeled with an antiserum directed against the small GTPase Rab3. However, some of the Rab3 signal at the plasma membrane Scale bars: $2 \mu \mathrm{m}$. 


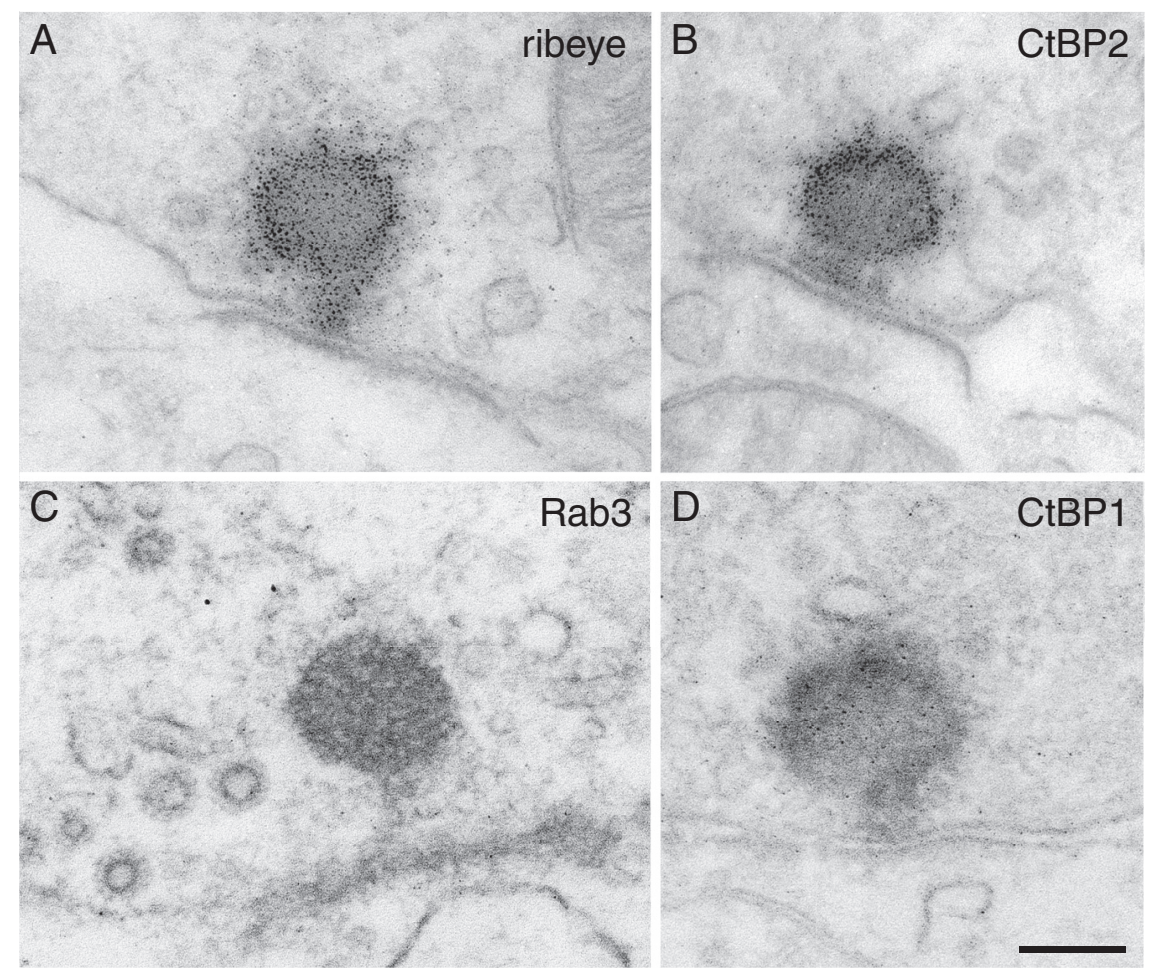

Figure 7. Immunoelectron microscopic localization of proteins at the synaptic junctions of cochlear hair cells. A, A presynaptic dense body or synaptic ribbon is densely labeled by silver grains conjugated to antiserum against CtBP2. The synaptic junction is clearly delineated by the dense labeling of the presynaptic membrane adjacent to the ribbon and the opposing postsynaptic membrane. In this and the subsequent panels, the tissue is lightly stained with lead to reveal membranes and other organelles. $\boldsymbol{B}$, A similar pattern of labeling is observed with antiserum against ribeye. $C$, An antiserum against anti-Rab3 labels not only the synaptic vesicles but also the ribbon. D, An antiserum directed against CtBP1 also marks the ribbon. Scale bars: $200 \mathrm{~nm}$.

\section{Discussion}

We used biochemical and proteomic techniques in conjunction with immunocytochemistry and electron microscopy to achieve a comprehensive description of the presynaptic apparatus for neurotransmitter release in hair cells. These results provide a basis for future studies on the composition and function of the hair-cell synapse.

We identified many synaptic proteins, including the synaptic SNARE molecules that likely mediate vesicle release at the haircell synapse. Synaptic-vesicle fusion is characterized by a rapidity and steep $\mathrm{Ca}^{2+}$ dependence that cannot be attributed to SNAREs alone (Südhof and Rothman, 2009). The proteins synaptotagmin 1 and complexin 1 are essential for maintaining the speed and synchrony of vesicle fusion at conventional synapses (FernandezChacon et al., 2001; Reim et al., 2001). In addition to its $\mathrm{Ca}^{2+}$ sensing property, synaptotagmin 1 is believed to position vesicles near $\mathrm{Ca}^{2+}$ channels (Chapman, 2008; Young and Neher, 2009). In hair cells, synaptotagmin 1 seems to be replaced by otoferlin, which has been identified as the principal $\mathrm{Ca}^{2+}$ sensor involved in hair-cell exocytosis (Roux et al., 2006) and was abundantly isolated in our purifications. In agreement with another report (Strenzke et al., 2009), we did not observe expression of complexins at the hair-cell synapse. In contrast, the photoreceptor's ribbon synapse requires complexins 3 and 4 but not complexins 1 and 2 (Reim et al., 2009). Complexins are thought to be critical for normal exocytosis in all neurosecretory systems (Brose, 2008). Complexins 1 and 2 have been shown to negatively regulate the fusion of the primed SNARE complex, thus impeding spontaneous release at conventional synapses. Because hair cells continuously release neurotransmitter in response to graded changes in membrane potential, they may not require the regulatory activity of complexins 1 and 2. Another possibility is that the hair-cell analog of complexin has not been identified. Finally, transmitter release mediated by otoferlin may differ from that regulated by synaptotagmin and complexin.

The process of vesicle docking and priming at the ribbon is not well understood. It is unclear whether the ribbonassociated vesicles are merely tethered or whether they are additionally primed for release. The principal role of the priming reactions is the regulation of two specific SNARE interactions. The first is the dissociation of used SNARE complexes and of unproductive complexes of SNAP25 and syntaxin 1 by $\alpha$-SNAP, $\beta$-SNAP, and NSF (Söllner et al., 1993). We observe large amounts of these three proteins in hair cells. The second interaction is the formation of new SNARE complexes, which requires the release of munc18 from syntaxin to foster the open conformation conducive to SNAP25 binding (Südhof and Rothman, 2009). Although the mechanism that switches syntaxin from its closed to its open conformation is uncertain, it is believed to require the activezone proteins munc13-1 and RIM (Betz et al., 2001). Knock-out mice lacking munc13-1 and its splice variant munc13-2, as well as Conorhabditis unc13 mutants lacking the homolog of munc13-1, display nearly complete loss of neurotransmitter release (Richmond et al., 1999). Neurotransmission is additionally impaired in nematode and murine mutants of RIM (Koushika et al., 2001; Schoch et al., 2002). Munc18-1 has also been found to bind the SNARE complex, and deletion of the munc18-1 gene abolishes synaptic secretion (Verhage et al., 2000; Dulubova et al., 2007). Synaptic-vesicle priming must therefore coordinate munc18, munc13, and RIM to prevent the formation of nonspecific SNARE complexes and thus restrict vesicle fusion to the active zone. We observed in hair cells expression of both munc18 and RIM, but an absence of munc13-1. The lack of munc13-1 at hair-cell synapses suggests that a different mechanism favors the open conformation of syntaxin. RIM1 and RIM2 have recently been reported to occur in immature murine inner hair cells but to be missing from mature cells (Gebhart et al., 2010).

It is possible that the localization of vesicles on a synaptic ribbon itself primes them for release. Vesicle docking is considered a property of SNARE-complex formation and of the interaction between Rab3 and RIM (Wang et al., 1997). Our experiments indicate a dense distribution of Rab3 on the ribbon. We propose that the vesicle protein Rab3 plays a role in docking vesicles to the ribbon, possibly by interacting with ribbonassociated RIM. Identifying Rab3's binding partners in hair cells would facilitate the analysis of this interaction. Rab escort protein 1 (REP-1) has been shown to be essential for the growth and survival of hair cells in the zebrafish's inner ear and lateral line (Starr et al., 2004). REP binds some newly synthesized Rabs in preparation for prenylation, a posttranslational modification that provides a basis for targeting Rabs to membranes. Rab3A and 
Rab3D are able to bind REP and are modified by geranylgeranylation (Pavlos et al., 2005; Baron and Seabra, 2008). Detailed analysis of the Rab3-interacting proteins could elucidate the ribbon-vesicle interaction. We have identified some Rab3 effectors, such as Rab3 GAP, rabphilin 3A, and the neuron-specific GDP-dissociation inhibitor $\alpha$ (Rab GDI $\alpha$ ), all of which have been shown to regulate synaptic transmission (Südhof, 1997; Takai et al., 2001). A large-scale genetic screen to identify proteins necessary for bruchpilot localization to the presynaptic densities or T-bars of the Drosophila neuromuscular junction revealed that Rab3 is involved in the recruitment of presynaptic release proteins at individual active zones (Graf et al., 2009). This property and its localization within the ribbons suggest that Rab3 has synaptic functions apart from vesicle docking at the active zone.

Several proteins involved in the localization of vesicles to the active zone are excluded from ribbon synapses. Synapsin has so far been absent from all ribbon synapses. At conventional synapses, synapsins tether synaptic vesicles to each other and to an actin-based cytoskeletal meshwork, securing a reserve pool of vesicles in the vicinity of the active zone (Greengard et al., 1993). Perturbation of synapsin function leads to disruption of the reserve pool and an increase in synaptic depression, suggesting that the synapsin-dependent cluster of vesicles is required for sustained release of neurotransmitter during high levels of neuronal activity. The absence of synapsins at ribbon synapses suggests that the mechanisms for vesicle clustering and mobilization in these terminals differ from those of conventional synapses. Synaptophysin was also absent from our hair-cell preparations. Because the synaptophysin-synaptobrevin complex is critical for synaptic-vesicle maturation at conventional synapses (Becher et al., 1999), the ribbon may compensate for the absence of these proteins by tethering and immobilizing a large pool of vesicles near the active zone.

In fractionation experiments, we isolated multiple nonneuronal SNAREs that are thought to occur either in the Golgi apparatus or in early or late endosomes. For example, we observed expression of SNARE molecules involved in endosomal fusion, suggesting that synaptic vesicles communicate with endosomal intermediates in their life cycle. Our localization studies showed labeling of several exocytotic and endocytotic proteins not only in the basolateral but also in the apical regions of hair cells. Novel membrane structures have been found previously in the apical and basal compartments of inner hair cells (Spicer et al., 1999), suggesting specialized membrane trafficking in these cells. Using a method for the purification of synaptic proteins that has been used previously for the purification of rat-brain vesicles (Takamori et al., 2006), we isolated a large number of synaptic proteins from the hair-cell synapse. However, we also extracted proteins originating from intracellular organelles, a result that could signal the isolation of all hair-cell vesicles by our procedure. This may explain the strong expression of $\beta$-COP (COP I coat protein) and Sec13 (COP II coat protein) in our fractionation experiments.

Some of the proteins we identified have also been isolated from hair bundles (Shin et al., 2007) and may therefore represent contaminants expressed at high levels throughout the hair cell. These proteins include cytoskeletal proteins such as actins, tubulins, and their chaperone t-complex polypeptide-1 (TCP1); brain-specific creatine kinase; peripheral membrane proteins such as annexin-A5 and phosphatidyl-ethanolamine binding protein (PEBP); and proteins involved in $\mathrm{Ca}^{2+}$ sequestration and removal such as parvalbumin 3, calmodulin, calretinin, and PMCA2. Also commonly identified were histones $\mathrm{H} 2 \mathrm{~A}$ and $\mathrm{H} 4$, molecular chaperones such as Hsp70 and GRP74, mitochondrial proteins such as ATP synthase $\alpha$ subunit and voltage-dependent anion-selective channel protein 2 (VDAC2), and enzymes involved in energy metabolism.

In summary, we confirmed using various methodologies that many proteins described at other synapses also occur at the ribbon synapses of hair cells. We established the presence of the neuronal SNAREs necessary for vesicle release as well as of other SNAREs involved in intracellular trafficking. We noted not only the presence of hair cell-specific proteins but also the exclusion of various vesicle-regulatory components. We identified many trafficking proteins localized to the apex or the base of the hair cell. Although we cannot demonstrate definitively the presence of all the proteins identified, our results provide a basis for future molecular analysis of ribbon synapses. Finally, we confirmed that the hair cell's synaptic ribbon is composed primarily of the CtBP family of proteins and is associated with the GTPase Rab3, a protein that may play a role in docking vesicles to the ribbon.

\section{References}

Alpadi K, Magupalli VG, Kappel S, Koblitz L, Schwarz K, Seigel GM, Sung CH, Schmitz F (2008) RIBEYE recruits Munc119, a mammalian ortholog of the Caenorhabditis elegans protein unc119, to synaptic ribbons of photoreceptor synapses. J Biol Chem 283:26461-26467.

Baron RA, Seabra MC (2008) Rab geranylgeranylation occurs preferentially via the pre-formed REP-RGGT complex and is regulated by geranylgeranyl pyrophosphate. Biochem J 415:67-75.

Becher A, Drenckhahn A, Pahner I, Margittai M, Jahn R, Ahnert-Hilger G (1999) The synaptophysin-synaptobrevin complex: a hallmark of synaptic vesicle maturation. J Neurosci 19:1922-1931.

Betz A, Thakur P, Junge HJ, Ashery U, Rhee JS, Scheuss V, Rosenmund C, Rettig J, Brose N (2001) Functional interaction of the active zone proteins Munc13-1 and RIM1 in synaptic vesicle priming. Neuron 30:183-196.

Brose N (2008) For better or for worse: complexins regulate SNARE function and vesicle fusion. Traffic 9:1403-1413.

Chapman ER (2008) How does synaptotagmin trigger neurotransmitter release? Annu Rev Biochem 77:615-641.

Corwin JT, Warchol ME (1991) Auditory hair cells: structure, function, development, and regeneration. Annu Rev Neurosci 14:301-333.

Dulubova I, Khvotchev M, Liu S, Huryeva I, Südhof TC, Rizo J (2007) Munc18-1 binds directly to the neuronal SNARE complex. Proc Natl Acad Sci U S A 104:2697-2702.

Fernandez-Chacon R, Konigstorfer A, Gerber SH, Garcia J, Matos MF, Stevens CF, Brose N, Rizo J, Rosenmund C, Südhof TC (2001) Synaptotagmin I functions as a calcium regulator of release probability. Nature 410:41-49.

Galvin JE, Uryu K, Lee VM, Trojanowski JQ (1999) Axon pathology in Parkinson's disease and Lewy body dementia hippocampus contains alpha-, beta-, and gamma-synuclein. Proc Natl Acad Sci U S A 96:13450-13455.

Garner CC, Kindler S, Gundelfinger ED (2000) Molecular determinants of presynaptic active zones. Curr Opin Neurobiol 10:321-327.

Gebhart M, Juhasz-Vedres G, Zuccotti A, Brandt N, Engel J, Trockenbacher A, Kaur G, Obermair GJ, Knipper M, Koschak A, Striessnig J (2010) Modulation of Cav1.3 $\mathrm{Ca}^{2+}$ channel gating by Rab3 interacting molecule. Mol Cell Neurosci 44:246-259.

Glowatzki E, Fuchs PA (2002) Transmitter release at the hair cell ribbon synapse. Nat Neurosci 5:147-154.

Graf ER, Daniels RW, Burgess RW, Schwarz TL, DiAntonio A (2009) Rab3 dynamically controls protein composition at active zones. Neuron 64:663-677.

Greengard P, Valtorta F, Czernik AJ, Benfenati F (1993) Synaptic vesicle phosphoproteins and regulation of synaptic function. Science 259: $780-785$.

He DZ, Dallos P (2000) Properties of voltage-dependent somatic stiffness of cochlear outer hair cells. J Assoc Res Otolaryngol 1:64-81.

Huttner WB, Schiebler W, Greengard P, De Camilli P (1983) Synapsin I (protein I), a nerve terminal-specific phosphoprotein. III. Its association with synaptic vesicles studied in a highly purified synaptic vesicle preparation. J Cell Biol 96:1374-1388. 
Katsumata O, Ohara N, Tamaki H, Niimura T, Naganuma H, Watanabe M, Sakagami H (2009) IQ-ArfGEF/BRAG1 is associated with synaptic ribbons in the mouse retina. Eur J Neurosci 30:1509-1516.

Keen EC, Hudspeth AJ (2006) Transfer characteristics of the hair cell's afferent synapse. Proc Natl Acad Sci U S A 103:5537-5542.

Khimich D, Nouvian R, Pujol R, tom Dieck S, Egner A, Gundelfinger ED, Moser T (2005) Hair cell synaptic ribbons are essential for synchronous auditory signalling. Nature 434:889-894.

Koushika SP, Richmond JE, Hadwiger G, Weimer RM, Jorgensen EM, Nonet ML (2001) A post-docking role for active zone protein Rim. Nat Neurosci 4:997-1005.

Kumarathasan P, Mohottalage S, Goegan P, Vincent R (2005) An optimized protein in-gel digest method for reliable proteome characterization by MALDI-TOF-MS analysis. Anal Biochem 346:85-89.

Lenzi D, von Gersdorff H (2001) Structure suggests function: the case for synaptic ribbons as exocytotic nanomachines. Bioessays 23:831-840.

Li GL, Keen E, Andor-Ardo D, Hudspeth AJ, von Gersdorff H (2009) The unitary event underlying multiquantal EPSCs at a hair cell's ribbon synapse. J Neurosci 29:7558-7568.

LoGiudice L, Matthews G (2009) The role of ribbons at sensory synapses. Neuroscientist 15:380-391.

Magupalli VG, Schwarz K, Alpadi K, Natarajan S, Seigel GM, Schmitz F (2008) Multiple RIBEYE-RIBEYE interactions create a dynamic scaffold for the formation of synaptic ribbons. J Neurosci 28:7954-7967.

Moser T, Beutner D (2000) Kinetics of exocytosis and endocytosis at the cochlear inner hair cell afferent synapse of the mouse. Proc Natl Acad Sci U S A 97:883-888.

Ng EL, Tang BL (2008) Rab GTPases and their roles in brain neurons and glia. Brain Res Rev 58:236-246.

Nouvian R, Beutner D, Parsons TD, Moser T (2006) Structure and function of the hair cell ribbon synapse. J Membr Biol 209:153-165.

Obholzer N, Wolfson S, Trapani JG, Mo W, Nechiporuk A, Busch-Nentwich E, Seiler C, Sidi S, Söllner C, Duncan RN, Boehland A, Nicolson T (2008) Vesicular glutamate transporter 3 is required for synaptic transmission in zebrafish hair cells. J Neurosci 28:2110-2118.

Parsons TD, Lenzi D, Almers W, Roberts WM (1994) Calcium-triggered exocytosis and endocytosis in an isolated presynaptic cell: capacitance measurements in saccular hair cells. Neuron 13:875-883.

Pavlos NJ, Xu J, Riedel D, Yeoh JS, Teitelbaum SL, Papadimitriou JM, Jahn R, Ross FP, Zheng MH (2005) Rab3D regulates a novel vesicular trafficking pathway that is required for osteoclastic bone resorption. Mol Cell Biol 25:5253-5269.

Reim K, Mansour M, Varoqueaux F, McMahon HT, Südhof TC, Brose N, Rosenmund C (2001) Complexins regulate a late step in $\mathrm{Ca}^{2+}$. dependent neurotransmitter release. Cell 104:71-81.

Reim K, Regus-Leidig H, Ammermuller J, El-Kordi A, Radyushkin K, Ehrenreich H, Brandstatter JH, Brose N (2009) Aberrant function and structure of retinal ribbon synapses in the absence of complexin 3 and complexin 4. J Cell Sci 122:1352-1361.

Richmond JE, Davis WS, Jorgensen EM (1999) UNC-13 is required for synaptic vesicle fusion in C. elegans. Nat Neurosci 2:959-964.

Roberts WM, Jacobs RA, Hudspeth AJ (1991) The hair cell as a presynaptic terminal. Ann N Y Acad Sci 635:221-233.

Roux I, Safieddine S, Nouvian R, Grati M, Simmler MC, Bahloul A, Perfettini I, Le Gall M, Rostaing P, Hamard G, Triller A, Avan P, Moser T, Petit C (2006) Otoferlin, defective in a human deafness form, is essential for exocytosis at the auditory ribbon synapse. Cell 127:277-289.

Rutherford MA, Roberts WM (2006) Frequency selectivity of synaptic exocytosis in frog saccular hair cells. Proc Natl Acad Sci U S A 103:28982903.

Rutherford MA, Roberts WM (2009) Spikes and membrane potential oscillations in hair cells generate periodic afferent activity in the frog sacculus. J Neurosci 29:10025-10037.
Safieddine S, Wenthold RJ (1999) SNARE complex at the ribbon synapses of cochlear hair cells: analysis of synaptic vesicle- and synaptic membraneassociated proteins. Eur J Neurosci 11:803-812.

Schmitz F (2009) The making of synaptic ribbons: how they are built and what they do. Neuroscientist 15:611-624.

Schoch S, Castillo PE, Jo T, Mukherjee K, Geppert M, Wang Y, Schmitz F, Malenka RC, Südhof TC (2002) RIM1alpha forms a protein scaffold for regulating neurotransmitter release at the active zone. Nature 415:321-326.

Seal RP, Akil O, Yi E, Weber CM, Grant L, Yoo J, Clause A, Kandler K, Noebels JL, Glowatzki E, Lustig LR, Edwards RH (2008) Sensorineural deafness and seizures in mice lacking vesicular glutamate transporter 3. Neuron 57:263-275.

Shin JB, Streijger F, Beynon A, Peters T, Gadzala L, McMillen D, Bystrom C, Van der Zee CE, Wallimann T, Gillespie PG (2007) Hair bundles are specialized for ATP delivery via creatine kinase. Neuron 53:371-386.

Söllner T, Bennett MK, Whiteheart SW, Scheller RH, Rothman JE (1993) A protein assembly-disassembly pathway in vitro that may correspond to sequential steps of synaptic vesicle docking, activation, and fusion. Cell 75:409-418.

Spicer SS, Thomopoulos GN, Schulte BA（1999) Novel membranous structures in apical and basal compartments of inner hair cells. J Comp Neurol 409:424-437.

Starr CJ, Kappler JA, Chan DK, Kollmar R, Hudspeth AJ (2004) Mutation of the zebrafish choroideremia gene encoding Rab escort protein 1 devastates hair cells. Proc Natl Acad Sci U S A 101:2572-2577.

Sterling P, Matthews G (2005) Structure and function of ribbon synapses. Trends Neurosci 28:20-29.

Strenzke N, Chanda S, Kopp-Scheinpflug C, Khimich D, Reim K, Bulankina AV, Neef A, Wolf F, Brose N, Xu-Friedman MA, Moser T (2009) Complexin-I is required for high-fidelity transmission at the endbulb of held auditory synapse. J Neurosci 29:7991-8004.

Südhof TC (1997) Function of Rab3 GDP-GTP exchange. Neuron 18:519-522.

Südhof TC, Rothman JE (2009) Membrane fusion: grappling with SNARE and SM proteins. Science 323:474-477.

Takai Y, Sasaki T, Matozaki T (2001) Small GTP-binding proteins. Physiol Rev 81:153-208.

Takamori S, Holt M, Stenius K, Lemke EA, Grønborg M, Riedel D, Urlaub H, Schenck S, Brügger B, Ringler P, Müller SA, Rammner B, Gräter F, Hub JS, De Groot BL, Mieskes G, Moriyama Y, Klingauf J, Grubmüller H, Heuser J, Weiland F, Jahn R (2006) Molecular anatomy of a trafficking organelle. Cell 127:831-846.

tom Dieck S, Altrock WD, Kessels MM, Qualmann B, Regus H, Brauner D, Fejtova A, Bracko O, Gundelfinger ED, Brandstatter JH (2005) Molecular dissection of the photoreceptor ribbon synapse: physical interaction of Bassoon and RIBEYE is essential for the assembly of the ribbon complex. J Cell Biol 168:825-836.

Verhage M, Maia AS, Plomp JJ, Brussaard AB, Heeroma JH, Vermeer H, Toonen RF, Hammer RE, van den Berg TK, Missler M, Geuze HJ, Südhof TC (2000) Synaptic assembly of the brain in the absence of neurotransmitter secretion. Science 287:864-869.

Von Kriegstein K, Schmitz F, Link E, Südhof TC (1999) Distribution of synaptic vesicle proteins in the mammalian retina identifies obligatory and facultative components of ribbon synapses. Eur J Neurosci 11: $1335-1348$

Wang Y, Okamoto M, Schmitz F, Hofmann K, Südhof TC (1997) Rim is a putative Rab3 effector in regulating synaptic-vesicle fusion. Nature 388:593-598.

Young SM Jr, and Neher E (2009) Synaptotagmin has an essential function in synaptic vesicle positioning for synchronous release in addition to its role as a calcium sensor. Neuron 63:482-496. 